\title{
Development of Senior High School Pancasila \& Civics Learning by Utilizing Contemporary Issues to Increase Civic Competence
}

\author{
Totok Suyanto*) \\ Pancasila and Civic Education \\ Department \\ Faculty of Law Social Sciences, \\ Universitas Negeri Surabaya \\ Surabaya, East Java, Indonesia \\ totoksuyanto@unesa.ac.id \\ Harmanto \\ Pancasila and Civic Education \\ Department \\ Faculty of Law Social Sciences, \\ Universitas Negeri Surabaya \\ Surabaya, East Java, Indonesia \\ harmanto@unesa.ac.id
}

\author{
Ari Wahyudi \\ Sociology Department \\ Faculty of Social Sciences, \\ Universitas Negeri Manado \\ Tondano, North Sulawesi, Indonesia \\ janrattu@unima.ac.id
}

\author{
Turhan Yani \\ Pancasila and Civic Education \\ Department \\ Faculty of Law Social Sciences, \\ Universitas Negeri Surabaya \\ Surabaya, East Java, Indonesia \\ turhanyani@unesa.ac.id
}

\begin{abstract}
The development of science and technology, especially information and communication technologies have a real impact on the creation of human social relations. Social relations in the present era is not only done in the form of physical contact, but more is done virtually, through the use of various social media. In the civic arena has now developed two concepts of citizenship. First, it physically citizenship (citizenship) as we have known and be a determinant of identity. Second, virtual citizenship (netizen-ship) that do not appear physically, but an integral part of the dynamics of citizenship and influencing the decision-making of state administration. The approach in this study using a combination of qualitative and development (development research) or so-called mixed-method research. Research and development by using the 4D model that includes Define, Design, Develop, and Dissemination
\end{abstract}

Keywords: Learning Model, contemporary issues, competence citizenship

\section{INTRODUCTION}

The phenomenon that occurs in Indonesia with the massive use of social media in strengthening the legitimacy and justification that Indonesia entered the era now called the era of "disruption" which is one of the characteristics of the era of the Industrial Revolution 4.0 (RI 4.0). RI 4.0 in the era in which one patron is the sophistication of the Internet as a global network, the development of the world's information is already massive and occurs at the same time.

In view Chairul (the Center, 12.30.2018) President director of CT corporation currently experiencing two disruptions of the Indonesian nation, namely (a) the technology as a result of the RI 4.0. and (b) and lifestyle, because of the generational change that causes a change in lifestyle.[1]The implications of the situation come to the values and new challenges, one of which is employed to be reduced because of life dominated by technology. For the mastery of science and technology, combined with innovation and creativity into keywords.
In reality, the sophistication of the technology that exists today finally requires that in addition to skills in operating, it also requires an understanding of ethics as the basis for media literacy to balance the negative impact of the technological sophistication. Without accompanied by responsibility and ethical awareness, the use of technology prone to tampering and irregularities function. One was the widespread distribution of false news (hoaxes) and speech of hatred (hate speech) in a variety of social media.

In the context of citizenship, Milner states that media literacy skills are one of the competences of literacy citizenship (civic literacy). Therefore, communication skills using a variety of sophisticated communication technology devices need to be supported by adequate literacy skills by the user.[2]The Hi-tech principle needs to be backed by Hitouch. The sophistication of the technology needs to be accompanied by high culture. Unfortunately, cross-country data shows that awareness and reading habits Indonesian people occupied the position for 63 of 64 countries are being surveyed. Indonesia is only better than Botswana, a small country in parts of Africa. As a result of the use of social media as a communication,the medium is not going as it should, as devices and media in the formation of community interests, slander, gossip, hatred speech, false news (hoax), insults and obscenities became a common sight in a variety of social media in Indonesia.[3]

Hoax and utterances are mainly related to political hatred are largely associated with the campaign of the presidential candidate in a general election, 2019. The intolerance of behavior that occurs mainly in cities already indicates since the 2010s. That if it is based by a survey conducted by various non-governmental organizations and universities, and government organizations (EQUIVALENT INSTITUTE 2010-2017; Gusdurian, 2015, 2016/2017; LIPI, 2016. UIN Syarif Hidayatullah, 2017) 
The study of diverse concluded that (1) the occurrence of intolerance in society, especially in the urban population; 2) Public support for the Homeland Pancasila, has decreased, but the number of citizens who support the Homeland Sharia it has increased. The decline in the spirit of inclusiveness in the community turned out at the same time to improve the understanding of exclusivity and in turn fertilize the anti tolerance and radicalism based on religion. The situation, in the long run, will harm the unity of the nation of Indonesia. Whereas as a pluralistic nation, our national construction consists of various elements and elements that form the atmosphere of mysticism finally us as a nation. Based on the description above, so the main problems faced by the nation-state in the world today is how to recognize and give legitimacy differences and construct a national identity that accommodates a variety of voices, experiences, expectations of different groups that make up the state of the nation.[4]

In the context of citizenship, Milner said that media literacy skills are one of the competencies literate citizenship. As the competence requirements of citizenship, media literacy in communication skills, responsibility for correspondence is the need of every citizen, so that in conducting the utilization of public space become more wise, ethical, and responsible. This is a new paradigm in civic education that aims to form an intelligent citizen and responsible.[2]

As stated above, the level of skills and low literacy in the digital era led to the use of technology that is not competent, the use of potentially irresponsible. It required competence in the use of the technology known as digital literacy.[5] Literacy digital is the ability to: a) use technology competently, b) understand and interpret digital content and measure its credibility, c) creating, researching, and communicating with the appropriate tools and appropriate. Digital literacy programs are essential elements in media education and involves the basic learning tools and curricula for critical and creative thinking skills. Digital literacy is an important part of civic citizenship,

In the current era of democratization of every citizen to freedom of opinion orally or in writing, then the phenomenon of deception is one thing that should be a common concern. In the current era of democratization of every citizen to freedom of opinion orally or writing, then the phenomenon hoaxis one thing that should be a common concern.[6]It could be a hoax false idea, the principle of the offensive, media manipulation, balance, objectivity, neutrality is a moral. [7]False ideas can be proven through real devastating results. The principle of freedom and tolerance that are contrary can never be reconciled. But the false idea that generates hate speech and could undermine social cohesion and should be excluded from freedom of expression.

To solve the above problems, an attempt to do is aware through formal education. Education is considered capable of performing reconstruction, interpretation, and implementation in the words and actions of values to build a culture of inclusiveness.[8]Therefore, various parties believe that education will be able to provide a significant impact on the prevention of acts hoax, hate speech, intolerance, radicalism attitude, and the like. One of the subjects that may develop tolerance, anti hoax, hateful speech, and unity in diversity is Pancasila and Civics Education

The development of Science, Technology and the Arts (science and technology), especially the Internet, bring a fundamental change in all aspects of human life. Internet technology coupled with sophisticated cellular (Mobile) that can be utilized in social networking / social media. The sophistication of the technology was not directly proportional to the psychological preparation for their use. Various hoax and speech of hatred (hate speech) in a variety of social media is hard to resist, even a tendency to spread. The spread of false news and hateful speech has entered into the realm of law. Additionally tolerance, respect for differences in ethnicity, religion, race, sectarian dwindling, the opposite of intolerance, especially in religious life is getting stronger.[9]

To solve the above problems, an attempt to do is to aware through formal education. This is because education is a process of acculturation. Education is considered capable of performing reconstruction, interpretation, and implementation in words and actions that build a culture of value (Suyanto, Harmanto, 2016: 3). Therefore, various parties believe that education will be able to provide a significant impact on the prevention of acts hoax, hate speech, intolerance, radicalism attitude, and the like. One of the subjects that may develop tolerance, anti hoax, hateful speech, and unity in diversity is Pancasila and Civics Education. In the 2013 curriculum subjects complete Pancasila and Civics Education competent yaki religious attitude (KI 1), social (KI 2), knowledge (KI 3), and Skills (KI 4).

Issues raised in the First Years of research are(1) Basic Competency (KD) anywhere in curricullum 2013 Pancasila and Civics Education subjects that can be developed by utilizing contemporary issues such as Hoax, hate speech (2) How did the teacher Pancasila and Civics Education SMA on utilization contemporary issues in learning Pancasila and Civics Education How does the design of learning development. Second Year (1) What is the feasibility study model Pancasila and Civics Education SMA by utilizing contemporary issues to increase civic competence of learners; (2) how the effectiveness of the learning model Pancasila and Civics Education SMA by utilizing contemporary issues to increase civic competence of learners.

The specific objectives to be achieved in the first year in this study were (1) to identify basic competencies anywhere in the curriculum of 2013 subjects Pancasila and Civics Education that can be developed by utilizing contemporary issues such as Hoax, the speech of hatred, slander, hate, etc. ; (2) obtain data on teacher responses Pancasila and Civics Education high school level concerning utilization contemporary issues in learning Pancasila and Civics Education How does the design of learning development. Second Year (1) Produce High School Pancasila and Civics Education learning model by utilizing contemporary issues to increase civic competence of learners who have been validated by experts; (2) analyze the effectiveness of the learning model Pancasila and Civics Education SMA by utilizing contemporary issues to increase civic competence of learners. 
This research will contribute in (1) expand the knowledge, attitudes, and behavior of learners anti hoax, expressions of hatred and danger to the life of society, nation, and state associated with ITE Law; (2) develop the knowledge, attitudes, behaviors to understand each the existence of ethnic, race, religion and group as a favor and (3) assist students in developing their competence as young citizens (young citizen) to build a culture of tolerance.

\section{METHOD}

The approach in this study using a combination of qualitative and development (development research) or socalled mixed-method research. Research and development by using the 4D model that includes defining, design, develop, and dissemination (Thiagarajan, Simmel, and Simmel, 1985). Define level doing by analyzing the basic competencies of Civics Curriculum 2013, learning material, positive and negative factors using contemporary issues in Senior High School. Design doing by creating the design of the Development of Pancasila and Civics learning by using contemporary issues. Develop doing by developing that design. Disseminate doing by using the design in field research.

\section{RESULTS AND DISCUSSION}

When a person is studying the internal process will happen to him include "phase of motivation, recognition, acquisition, retention, generalization, appearance, and feedback" (Gagne, 1985; 1989: 141-143). In the motivation phase, students should be given the expectation that learning is fun, and the information received will be useful to them, both to gain value and life. To that end, the teacher's role in learning what they need to maintain the attitude, sincere and thorough. Motivation did since the beginning, during, and at the end of the lesson.

In the context of Pancasila and Civics Education learning in school, Winataputra and Budimansyahstates that the weakness of Pancasila and Civics Education emphasizes learning instructional impacts are limited to the mastery of the material, whereas affective and psychomotor development dimension and the impact is still lacking companion got more servings.[10]Likewise, the results of research conducted the weakness of the learning values-moral (including Pancasila and Civics Education) only leads to a "continuum minimally characterized by thin, exclusive, elitist, formal, contented, knowledge-based, didactic transmission, Easier to archive and measure in practice ". Only Civics who has the burden of fostering moral values of citizens, "there is a distance between the teacher-student in classroom arrangement, the achievement of the materials being the main target, the orientation of the material, based on knowledge,

To achieve the maximum goal of learning civics needs to be done with a "maximal continuum marked by inclusive, activist, participative, process-led, value-based, interactive, and more difficult, to Achieve. If a continue maximum to be achieved, it can apply the learning theory of Bruner in learning.[11] One instructional model developed Brunner was very influential is learning the invention (discovery learning). Learning invention becauseof Bruner "... we teach a subject no to produce little living libraries on that subject, but rather to get a student to think mathematically for himself, to Consider matters as a historian does, to take part in the process of knowledge-getting. Knowing is a process, not a product ".
When teaching is not just to teach about science (science), but more than that should make students more involved in the process of acquiring knowledge.

Learning the discovery is "a form of problem-solving is not just to let the students do what they want to do, although often the discoveries made just happen" Although the chance, at least in the early stages of rules regulating activities by the teacher, followed by students looking, process, search, investigates until the conclusion. although often the discoveries made just happenAlthough the chance, at least in the early stages of rules regulating activities by the teacher, followed by students looking, process, search, investigates until the conclusion. although often the discoveries made just happen.[12] Although the chance, at least in the early stages of rules regulating activities by the teacher, followed by students looking, process, search, investigates until the conclusion.

In learning there is always a learning outcome to be achieved both in the domain of cognitive, affective, and psychomotor embodied in the form of abilities. Given learning outcomes are categorized into five, namely "(1) intellectual skills, (2) cognitive strategy, (3) verbal information, (4) attitude, and (5) the motor skills". The views Gagne about learning, in line with the competence of citizenship in the form of knowledge, values, attitudes, and skills of students in favor of "citizenship participatory and responsible in society and state". [13]Bronson confirms that the Civics goal is "to participate in good quality and responsibility in politics and society, both at local and national levels".[14]To participate to the maximum needed competencies citizenship, namely: "(1) the mastery of knowledge and a certain understanding, (2) development of intellectual abilities and participatory, (3) the development of the mental attitude of certain (4) a true commitment to the fundamental values and principles of constitutional democracy. The National Standards for Civics and Government formulated on the aspects of these competencies include "knowledge citizenship (civic knowledge), skills citizenship (civic skills), and the character or characters citizenship (civic dispositions)".

To participate to the maximum needed competencies citizenship, namely: "(1) the mastery of knowledge and a certain understanding, (2) development of intellectual abilities and participatory, (3) the development of the mental attitude of certain, (4) a true commitment to the fundamental values and principles of constitutional democracy. The National Standards for Civics and Government[15] formulated on the aspects of these competencies include "knowledge citizenship (civic knowledge), skills citizenship (civic skills), and the character or characters citizenship (civic dispositions)". To participate to the maximum needed competencies citizenship, namely: "(1) the mastery of knowledge and a certain understanding, (2) development of intellectual abilities and participatory, (3) the development of the mental attitude of certain, (4) a true commitment to the fundamental values and principles of constitutional democracy.

The National Standards for Civics and Government formulated on the aspects of these competencies include "knowledge citizenship (civic knowledge), skills citizenship (civic skills), and the character or characters citizenship (civic dispositions)". (2) development of intellectual abilities and participatory, (3) development and a certain mental attitude), (4) a true commitment to the fundamental values and principles of constitutional democracy. The National Standards for Civics and Government formulated on the 
aspects of these competencies include "knowledge citizenship (civic knowledge), skills citizenship (civic skills), and the character or characters citizenship (civic dispositions)". (2) development of intellectual abilities and participatory, (3) development and a certain mental attitude a true commitment to the fundamental values and principles of constitutional democracy.[16] The National Standards for Civics and Government) formulated on the aspects of these competencies include "knowledge citizenship (civic knowledge), skills citizenship (civic skills), and the character or characters citizenship (civic dispositions)".

To be a good citizen needed a set of basic knowledge such as rights and obligations, caring, sensitivity to public issues, democracy, and others. Knowledge citizenship is the basis and impetus for improving skills. Citizenship skills are the embodiment of the actual practice of knowledge. Implications of the acquisition of knowledge and skills sufficient citizens then internalized within expected to shape the character or characters, which shows the positive characteristics that stand out a nation.

\section{Define Phase}

In general competencies that must be achieved learners after learning the Pancasila and Citizenship Education in Senior High School.Based on the identification of the scope and competence in the subjects Pancasila and Civics SMAequivalent, identifying subject matter that can be integrated Pancasila and Civics contemporary issues. There are four scope need to be achieved. Pancasila, Constitution, Unitary State of The Republic of Indonesia, Unity in Diversity. Contemporary issues can be integrated with each scope. The issues are Human Rights abuses in Indonesia in Pancasila perspective, the challenge and the reality of Pancasila Democracy practice in Indonesia, the reality and the challenge of the legal system and judicial practice in Indonesia, Indonesia participation in World Peace relate to the constitution, the treat for ideology, politic, economic, culture, defense and national security, supporting factors and obstacle factor relate to unity and diversity in Indonesia.

\section{Design Phase}

Stage design development model of learning by utilizing contemporary issues starts from identified basic competencies and search the relevant issues to that competencies. The Development of the learning model was designed for Class X, XI, and XIII Senior High School. For Class $\mathrm{X}$, the issues which relevant to their basic competencies are Fighting Corruption which committed by the Regent/Mayor/ Governor, Asylum Seeker from the middle east who lives in sidewalk Kalideres, Students demonstration which standard for Indonesia's Corruption Eradication Commission, Acquisition of Freeport Shares by Indonesian Government, the dangerous of Hoax to attack ideology, politic, economic, social culture, and national security, infighting named by ethnic, race, religion, and group. For Class XI, the contemporary issues are terrorism as part of human rights abuse, President and Vice President election which destroys the unity because of the different political choices, hate speech in social media, and hate speech against the regulation of Bill of Act on Electronic Information and Transaction. For Class XII, the contemporary issues are Fighting corruption, the case of drug dealers who were sentenced to be free and do the same crime, dismissal of Army Official because of the hate speech which doing by his wife.

88,89 Pancasila \& Civics teachers in Senior High School strongly agreed that contemporary issues must be integrated into the curriculum. The rest teachers less agreed and not agreed. We conclude that most teachers are agreed to contextualize their material by using contemporary issues.

\section{Development Phase}

Learning Development Pancasila and Civics for Senior High School by utilizing contemporary issues: such as syllabus, Screenplay, Reading Materials, Media, Assessment Instrument. Documents Learning Tool, Syllabus, scenario, Reading Materials, Media, assessment instruments that have been validated, and the contents Pancasila and Civics Education learning experts, teachers Pancasila and Civics Education trial. Learning tools that have been developed to have a good quality validation by experts on Pancasila and Civics learning design. There was $90.57 \%$ expert valued that the learning tool is good enough for Class X learning tools, which means that the learning device feasible for field-tested in real learning.For Class XI, based on data there was an average score validator is $88.57 \%$, which means that the learning device feasible for field-tested in real learning. Based on data for Class XII, it shows that there was an average score validator is $93.33 \%$, which means that the learning device feasible for field-tested in real learning. Thelearning model deserves to be tested in the field.

\section{Disseminate Phase}

To the disseminate Development Model Learning of Pancasila And Civics education is the last phase. The activities in this phase are the ability of Teachers in implementing and using the learning model and the education processing in class Class X, XI, and XII.

According to the research result, 52,9\% of teachers valued very well in the ability to practice learning model with integrated contemporary issues. The rest, 47,06 was good enough. We can conclude that teachers have a strong ability to teach Pancasila and Civics with contemporary issues.

Theresult of observation shows that in Pancasila and Civics learning using contemporary issues in Class $\mathrm{X}$ shows that $47,06 \%$ good, and $52.94 \%$ excellent. This means that the learning tools Class X, by using of the issue of "Student Demonstration demanding the president to issue a Regulation to Replace Law about Indonesia's Corruption Eradication Commission(KPK), can be used in Pancasila and Civics learning

Theresult of observation shows that in Pancasila and Civics learning using contemporary issues in class II showed that $5.88 \%$ is quite good, good $58.82 \%$, and $14.86 \%$ excellent. This means that the learning tools Class XI, by the use of the issue of "The Case of convicted drug dealers are sentenced to be free, then circulate again and arrested by the police", can be used in Pancasila and Civics learning.

Observationresults show that in Pancasila and Civics learning using contemporary issues in Class XII showed that $47.06 \%$ is good and $52.94 \%$ is excellent. This means that the learning tools Class XII, by the use of the issue of "Cessation of military positions because of hate speech in social media that made his wife" can be used in Pancasila and Civics learning. 


\section{CONCLUSIONS AND SUGGESTIONS}

\section{A. Conclusion}

Based on the results of research and discussion that has been presented before conclusions can be submitted are:

1. Basic competencies in these subjects can be integrated with contemporary issues for going deeper into learning.

2. Generally, Pancasila and Civics teachers are agreed about the integration of contemporary issues as a basis for learning.

3. Developmentof learning tools or model with contemporary issues in school by placing subjects Pancasila and Civics as the core, the driving, the driving, the cutting edge that is directed at the impact of instructional and companion, while other subjects and extracurricular activities, as well as school culture geared to the impact of any companion.

4. Development learning tools or model with using contemporary issues are integrated with the learning Pancasila and Civicscan use the worksheets, a debate as to the pros and cons, and Problem Based Learning, can increase the activity and student motivation because it is based frame of constructivism and not only leads to activity recalling comprehension, but toward reflective thinking that is characterized by liveliness, creativity students in all learning activities.

5. The process of integration of contemporary issues model learning asbasic learningof Pancasila and Civics are:

a. Identification of basic competencies Pancasila and Civics subjects of class X, XI, and XII.

b. Identification material studies in Pancasila and Civics subjects of class X, XI, and XII.

c. Identification contemporary issues that exist in Indonesia which relate to the subject and material Pancasila and Civics subjects of class X, XI, and XII.

d. Integrate contemporary issues into basic competencies of Pancasila and Civics subjects of class X, XI, and XII

e. Determining the learning model that will be practiced.

f. Develop a Learning Tool or model.

\section{B. Suggestions}

1. Teachers needs good comitment to integrate contemporary issues to their learning material.

2. All teachers will be
3. In the future, to increase discipline, the leadership should apply strict sanctions for all employees who are not disciplined according to Government Regulation No. 53 of 2010 concerning the Discipline of Civil Servants and provide rewards for employees.

\section{REFERENCES}

[1] R. Almagor, Cohen, "Responsibility of and Trust in ISPs. Knowledge, technology and policy.," Marshall J. Comput. Inf. Law, vol. 23, no. 3, pp. 381-396, 2012.

[2] h Millner, "Civic Literacy, How Inform Citizens make democracy work," 2002

[3] K. Ralph, The Post Truth Era: Dishonesty And Deception In Contemporary Life. 2004.

[4] O. Audrey, "Human Rights and Schooling: An Ethical Framework for Teaching for Social Justice,” 2011.

[5] W. James Potter, "Argument for the Need for a CognitiveTheory of Media Literacy,” 2004.

[6] Brunner, Toward a Theory of Instruction. New York: Norton, 1996.

[7] Kompas, "Law Literation Produce Hoax," Kompas, p. 15, 2017

[8] T. Suyanto, I. M. Zen, K. Prasetyo, P. Isbandono, G. Gamaputra, and I. P. Purba, "The study perception of social sciences and law faculty students for hoax in social media," in Journal of Physics: Conference Series, 2018, vol. 953, no. 1.

[9] Kerr, Citizenship Education: an International Compariso. LONDON: NFER, 1999.

[10] Winataputra, Civic Education: The basic, Material Learning, dan Class Culture. Bandung: Sekolah Pasca Sarjana, 2007.

[11] B. Jerome, "The Culture of Education," Can. J. Educ., vol. 25, no. 3,2000 .

[12] D. Schunk, Learning Theories: An Educational Perspectives. New York, 2012.

[13] Gagne, The Conditioning of Learning. New York: Holt, Rinerhart and Winston., 1988.

[14] Bronson, Learning Civics Education from United State. Yogyakarta: LKIS, 1999.

[15] CICED, "Democratic Citizenship in a Civic Society :Report of The. Conference on Civic Education for Civic Society," 1999.

[16] B. Komalasari, "The Impact of Contextualize Learning for Civics Learning for Junior High School," Acta Civ. J. Pendidik. Kewarganegaraan, vol. 2, no. 1, 2008. 